\title{
Rapid Escape Response - A Behavioral Response on Eisenia fetida
}

Sneha Halwasia*, Manasvee Dhanesha, Hanisha Udhani and Keshav Deore

Department of Biotechnology, Thadomal Shahani Engineering College, Bandra(W), India

*Corresponding author: Sneha Halwasia, Department of Biotechnology, Thadomal Shahani Engineering College, Bandra(W), India, Tel: +91-9757282306; E-mail: snehahalwasia@gmail.com

Rec date: November 22, 2017; Acc date: January 05, 2018; Pub date: January 06, 2018

Copyright: $\odot 2018$ Halwasia S, et al. This is an open-access article distributed under the terms of the Creative Commons Attribution License, which permits unrestricted use, distribution, and reproduction in any medium, provided the original author and source are credited.

\begin{abstract}
A behavioral assay is described for studying locomotory behavior in annelid Eisenia fetida. This assay presents a method using a gustatory repellant Sodium Chloride $(\mathrm{NaCl})$ to induce a locomotory response in the earthworm. This assay helps us understand the ambulation that is under control of a well co-ordinated nervous system, precisely, the Ventral Nerve Cord. To confirm this a lesion was performed on the nerve cord and functional activity under the repellant was again assayed. Results suggest that an undamaged ventral nerve cord is essential for earthworms' rapid escape responses.
\end{abstract}

Keywords: Earthworm; Eisenia fetida; Ventral nerve cord; $\mathrm{NaCl}$; Locomotion; Assay

\section{Introduction}

How animals progressed from a simple nerve net to a complex centralized nervous system remains one of the most exciting and unsolved questions of animal evolution [1]. The nervous systems of invertebrate organisms often are designated for their spatially directed collections of neurons responsible for local control of operations, such as the thoracic or abdominal ganglia, which receive sensations and direct motoric responses for specific body segments, all under the general control of a cephalic ganglion whose role includes sensing the external environment [2-5].

Earthworms are used in an increasing number of microcosm experiments that investigate their behavior and biology or that consider earthworms an environmental factor that influences soil properties and biological interactions [6-11]. However, there exists no standardized protocol for performing comparable studies. The earthworm is a much studied species, and in recent years much work has been carried out with regard to the mechanism of its movement. Though there are several descriptions of the modes of movement, their neuronal control and the functional organization of the nervous system are less well understood. Nevertheless an understanding of the mechanisms involved is important to comparative neurophysiology since the earthworm probably stands midway in the evolution from non-myelinated to myelinated neurons and from simple nerve nets to organized reflex systems $[2,4,12-15]$.

The main nerve trunk, i.e., the ventral nerve cord in the earthworm, lies close to the inner median surface of the body wall, and runs from segment 4 to the rear end of the earthworm. It swells slightly to form a ganglionic enlargement in each segment [14].

Among annelids, the lumbricid earthworm, Eisenia fetida, which is important in breaking down organic wastes, has been used commonly for research into regeneration, because it is easy to culture and handle in the laboratory. Earthworms can tolerate moderate salinity but some earthworm species like Eisenia fetida are reported to be highly salt tolerant with 28-day $\mathrm{LC}_{50}$ of $\mathrm{NaCl}$ found to be $5436 \mathrm{mg} \mathrm{kg}^{-1}$ [16].
Considering these facts, we decided to use Eisenia fetida as our model organism. They were maintained in plastic cups containing moist tissue paper (source of cellulose) [17-21]. Test was performed in two sets, one set consisting of pre-clitellate juvenile animal and second of clitellate mature animals. Results were recorded. From this assay we determined the response of an earthworm to Sodium Chloride as well as necessity of an undamaged Ventral Nerve Cord to produce the response.

\section{Materials and Methods}

\section{Organisms used}

Earthworms of species Eisenia fetida bought from Yusuf Mehralli Centre (Mumbai). Using the general physiological characteristics of $E$. fetida, a confirmation of the identification of species was performed [22].

\section{Maintenance and nutrition}

Earthworms were maintained in cup cultures. Small holes were made using a thin edged screw driver in plastic cups. A thick layer of tissue paper was put inside and it was moistened with tap water. Since tissue paper is a source of cellulose, which serves as nutrient source for earthworms, they decompose the paper and survive on available cellulose. A muslin cloth was used to cover the cups. Cups were numbered serially and placed in sets of 10 each in different trays containing layers of newspapers on which water was added daily so that cups retained moisture. Clitellate and Pre-clitellate were marked differently.

\section{Rapid escape response assay}

\section{Materials}

Reagents: $200 \mathrm{mM} \mathrm{NaCl}$ solution, distilled water.

Distilled water is used as Control.

Apparatus and miscellaneous: 30 test tubes $(15 \mathrm{ml}), 10 \mathrm{ml}$ pipette, test tube rack, Timer, glass bowl with tap water, paint brush, filter paper. 
Page 2 of 6

Method: A clean dry testube was taken. $1 \mathrm{ml}$ of the solution (distilled water or $200 \mathrm{mM} \mathrm{NaCl}$ ) was added using glass pipette, taking care that it doesn't touch the walls of the test tube.

With the help of a brush, one worm from the cup culture was taken out gently and give it a brief wash in the bowl with tap water to remove any adhering castings.

The worm was picked up with the same brush, rolled and submerged in the solution. Care was taken that the worms do not touch glass wall and it is directly put into the solution.

The stop watch was started immediately; the time taken for the worm to climb completely out of the solution is recorded for a maximum of 2 min for preclitellate worms and 4 mins for clitellate worms. The first four steps were repeated for another readings; a new tube was used for every reading. The assay was repeated on all sets of worms. A total of 140 worms were used - 60 clitellate and 60 preclitellate. (plus an additional 10 clitellate and 10 pre-clitellate)

The protocol was performed once in 24 hours on earthworms with an undamaged ventral nerve cord.

Protocol to introduce lesion on ventral nerve cord [14]

- The earthworm was subjected to $1 \%$ chloroform for 1-2 mins.

- It was taken on a clean blotting paper.

- It was turned to its ventral buff side and near the 23-24 segments a oblique cut was made ensuring it just causes damage to ventral nerve cord and does not cause cut to entire body of worm.

- Cut was made using a sharp blade.

- Earthworm was washed with tap water to remove traces of chloroform.

- A sham lesion on the dorsal side was performed on 20 worms separately (10 clitellate, 10 Pre-clitellate).

The assay was again performed in the same manner as mentioned above on the 0th hour of the lesion for each worm.120 earthworms were lesioned on the VNC. Results were recorded.

\section{Results}

\section{Behavioral assay on juvenile Eisenia fetida with an undamaged ventral nerve cord}

The assay was performed on 60 pre-clitellate animals. Each worm was subjected to the control Distilled water for 2 mins and then to 200 $\mathrm{mM} \mathrm{NaCl}$ for two minutes. Time was decided based on reviewed data as well as first taking out an average time required for earthworms to escape $200 \mathrm{mM} \mathrm{NaCl}$. The time of escape was recorded for each earthworm. It was seen that all the earthworms do not show any movement in distilled water within the period of 2 minutes. In case of test tube containing $200 \mathrm{mM} \mathrm{NaCl}$ the earthworms use peristaltic movement and climb the wall of the glass test tube within the 2 minutes in order to escape the guststory repellant. Results of two sets were as follows: (Tables 1 and 2)

\begin{tabular}{|l|l|l|}
\hline Earthworm No. & Control (D/W) & $200 \mathrm{mM} \mathrm{NaCl}$ \\
\hline 1 & $\mathrm{X}$ & $00: 04$ \\
\hline 2 & $\mathrm{X}$ & $00: 03$ \\
\hline 3 & $\mathrm{X}$ & $00: 02$ \\
\hline
\end{tabular}

\begin{tabular}{|l|l|l|}
\hline 4 & $X$ & $00: 07$ \\
\hline 5 & $X$ & $00: 05$ \\
\hline 6 & $X$ & $00: 06$ \\
\hline 7 & $X$ & $00: 06$ \\
\hline 8 & $X$ & $00: 12$ \\
\hline 9 & $X$ & $00: 07$ \\
\hline 10 & $X$ & $00: 04$ \\
\hline
\end{tabular}

Table 1: Set 1.

\begin{tabular}{|l|l|l|}
\hline Earthworm No. & Control (D/W) & $200 \mathrm{mM} \mathrm{NaCl}$ \\
\hline 11 & $\mathrm{X}$ & $00: 05$ \\
\hline 12 & $\mathrm{X}$ & $00: 02$ \\
\hline 13 & $\mathrm{X}$ & $00: 05$ \\
\hline 14 & $\mathrm{X}$ & $00: 07$ \\
\hline 15 & $\mathrm{X}$ & $00: 04$ \\
\hline 16 & $\mathrm{X}$ & $00: 04$ \\
\hline 17 & $\mathrm{X}$ & $00: 05$ \\
\hline 18 & $\mathrm{X}$ & $00: 05$ \\
\hline 19 & $\mathrm{X}$ & 0.07 \\
\hline 20 & $\mathrm{X}$ & 0.04 \\
\hline
\end{tabular}

Table 2: Set 2.

Table shows response of individual earthworms on subjecting them with $\mathrm{D} / \mathrm{W}$ and $\mathrm{NaCl}$. Here timings are indicated minutes:seconds. $\mathrm{X}$ indicates failure to escape in 2 minutes.

Similar results were observed for the rest 40 Pre-clitellate animals.

\section{Behavioral assay on mature Eisenia fetida with an undamaged ventral nerve cord}

Assay was performed in a similar manner. However it was seen that response time required in clitellate animals was greater than juvenile ones. We first assayed the time required for the clitellate animal to escape $200 \mathrm{mM}$ of $\mathrm{NaCl}$ and then checked if they could stay in distilled water for a period slightly greater than average time required by all mature animals. Thus, we set a protocol for 4 minutes which was greater than the time required for most clitellate animals to escape 200 $\mathrm{mM} \mathrm{NaCl}$. Results were recorded in a similar manner. (Figures 1 and 2; Table 3) 
Citation: Halwasia S, Dhanesha M, Udhani H, Deore K (2018) Rapid Escape Response - A Behavioral Response on Eisenia fetida. J Vet Sci Technol 9: 502. doi:10.4172/2157-7579.1000502

Page 3 of 6

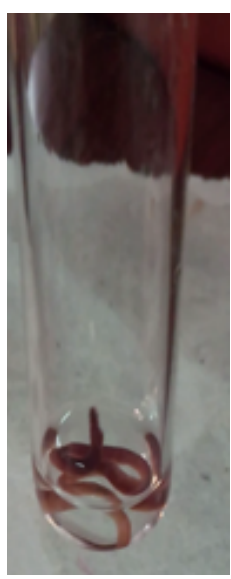

Figure 1: Indicates earthworm in D/W.
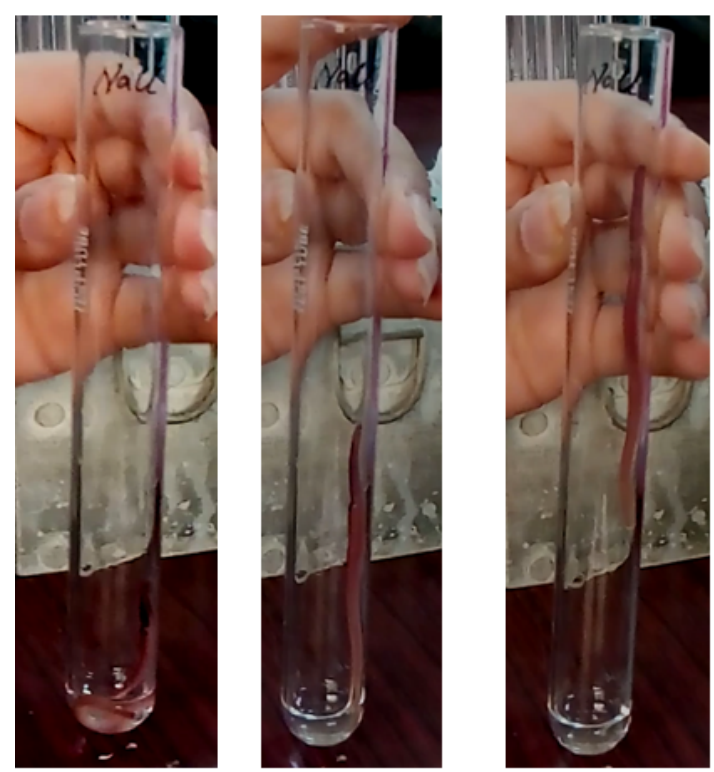

Figure 2: Indicates the recordings after earthworm was subjected to $200 \mathrm{mM} \mathrm{NaCl}$.

\begin{tabular}{|l|l|l|}
\hline Earthworm No. & Control (D/W) & $200 \mathbf{~ m ~ N a C l}$ \\
\hline 1 & $X$ & $02: 21$ \\
\hline 2 & $X$ & $03: 26$ \\
\hline 3 & $X$ & $01: 23$ \\
\hline 4 & $X$ & $01: 25$ \\
\hline 5 & $X$ & $00: 32$ \\
\hline 6 & $X$ & $02: 15$ \\
\hline 7 & $X$ & $01: 37$ \\
\hline 8 & $X$ & $03: 38$ \\
\hline
\end{tabular}

\begin{tabular}{|l|l|l|}
\hline 9 & $X$ & $03: 51$ \\
\hline 10 & $X$ & $02: 15$ \\
\hline 11 & $X$ & $02: 21$ \\
\hline 12 & $X$ & $03: 00$ \\
\hline 13 & $X$ & $01: 00$ \\
\hline 14 & $X$ & $01: 04$ \\
\hline 15 & $X$ & $00: 30$ \\
\hline 16 & $X$ & $02: 00$ \\
\hline 17 & $X$ & $01: 02$ \\
\hline 18 & $X$ & $03: 23$ \\
\hline 19 & $X$ & $03: 10$ \\
\hline 20 & $X$ & $02: 13$ \\
\hline
\end{tabular}

Table 3: Response of individual earthworms on subjecting them with $\mathrm{D} / \mathrm{W}$ and $\mathrm{NaCl}$.

Table shows response of individual earthworms on subjecting them with $\mathrm{D} / \mathrm{W}$ and $\mathrm{NaCl}$. Here timings are indicated minutes:seconds. $\mathrm{X}$ indicates failure to escape in 4 minutes.

\section{Behavioral assay on juvenile Eisenia fetida with a lesioned ventral nerve cord}

Each pre-clitellate earthworm was subjected to control as well as 200 $\mathrm{mM} \mathrm{NaCl}$ just after causing a lesion on the ventral nerve cord. The 0th hour readings were recorded in the same manner. No movement was seen in distilled water in 2 minutes. Then the worm was removed from $\mathrm{D} / \mathrm{W}$ and introduced in $200 \mathrm{mM} \mathrm{NaCl}$. No attempts of any escape were made by the worm of any kind in the two minutes.

\section{Behavioral assay on mature Eisenia fetida with a lesioned ventral nerve cord}

0th hour readings on clitellate animal was taken in the similar manner. No movement was seen in both control as well as $200 \mathrm{mM}$ $\mathrm{NaCl}$ in the given 4 minutes assay.

\section{Behavioral assay on juvenile as well as mature Eisenia fetida with a sham lesion on the dorsal body}

In both the cases no response was seen in distilled water in 2 minutes for juvenile and 4 minutes for mature worms. A locomotory response was observed in $200 \mathrm{mM} \mathrm{NaCl}$ in both cases just like the previously recorded response. Thus a sham on the dorsal side did not undamaged (Figures 3-7). disrupt the well co-ordinated locomotory response, as nerve cord was 
Citation: Halwasia S, Dhanesha M, Udhani H, Deore K (2018) Rapid Escape Response - A Behavioral Response on Eisenia fetida. J Vet Sci Technol 9: 502. doi:10.4172/2157-7579.1000502

Page 4 of 6

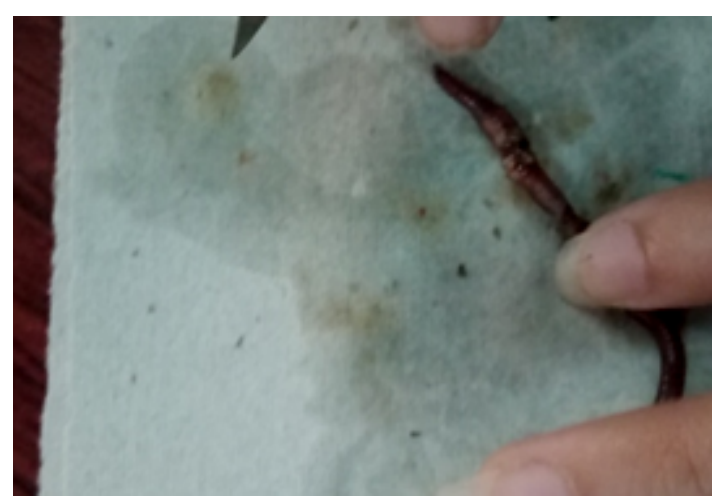

Figure 3: Shows preclitellate worm post lesion on ventral nerve cord.

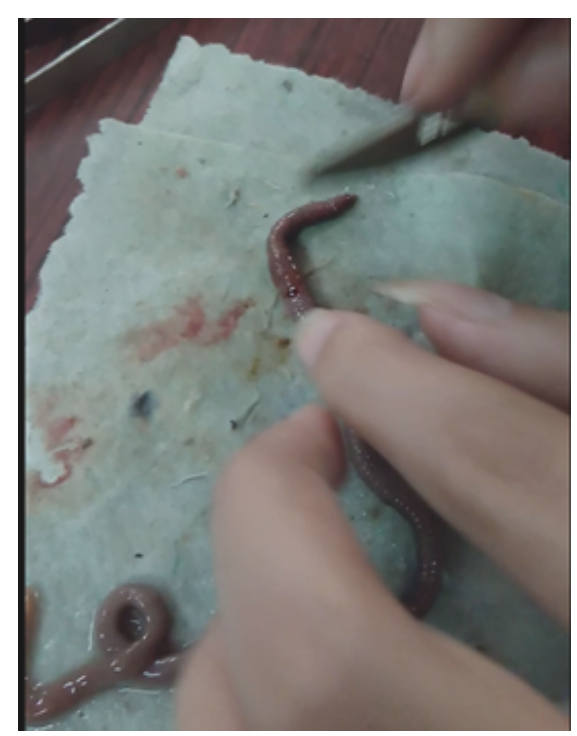

Figure 4: Shows clitellate worm post lesion on ventral nerve cord.

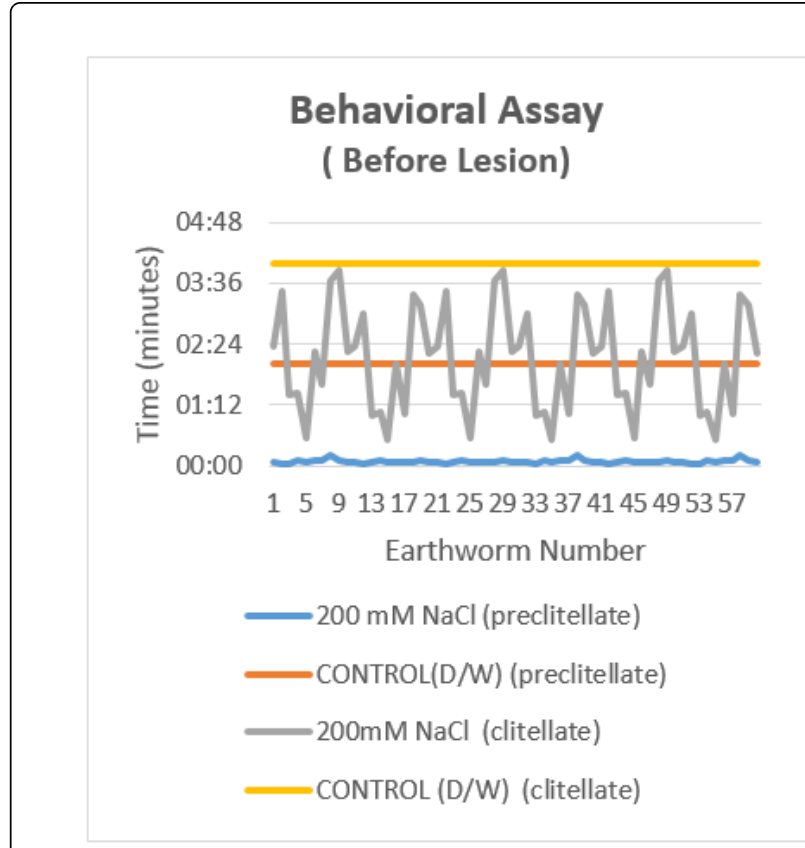

Figure 5: Behavioral assay before lesion.

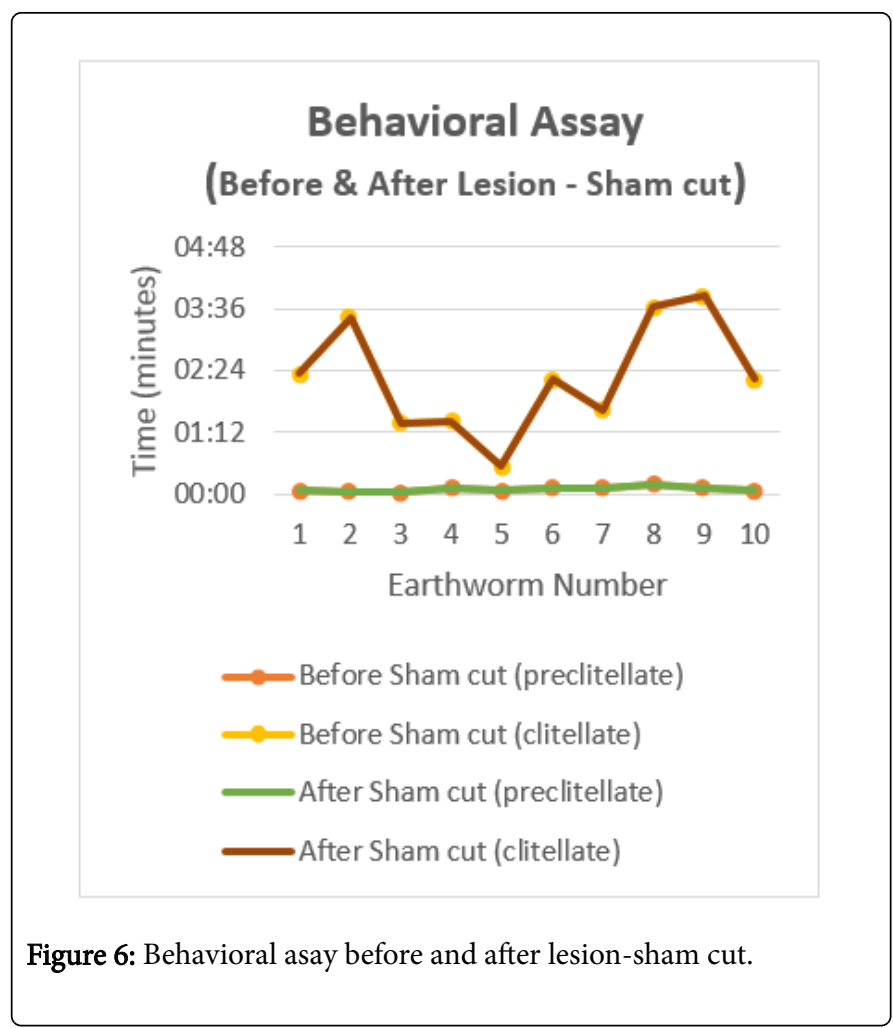


Page 5 of 6

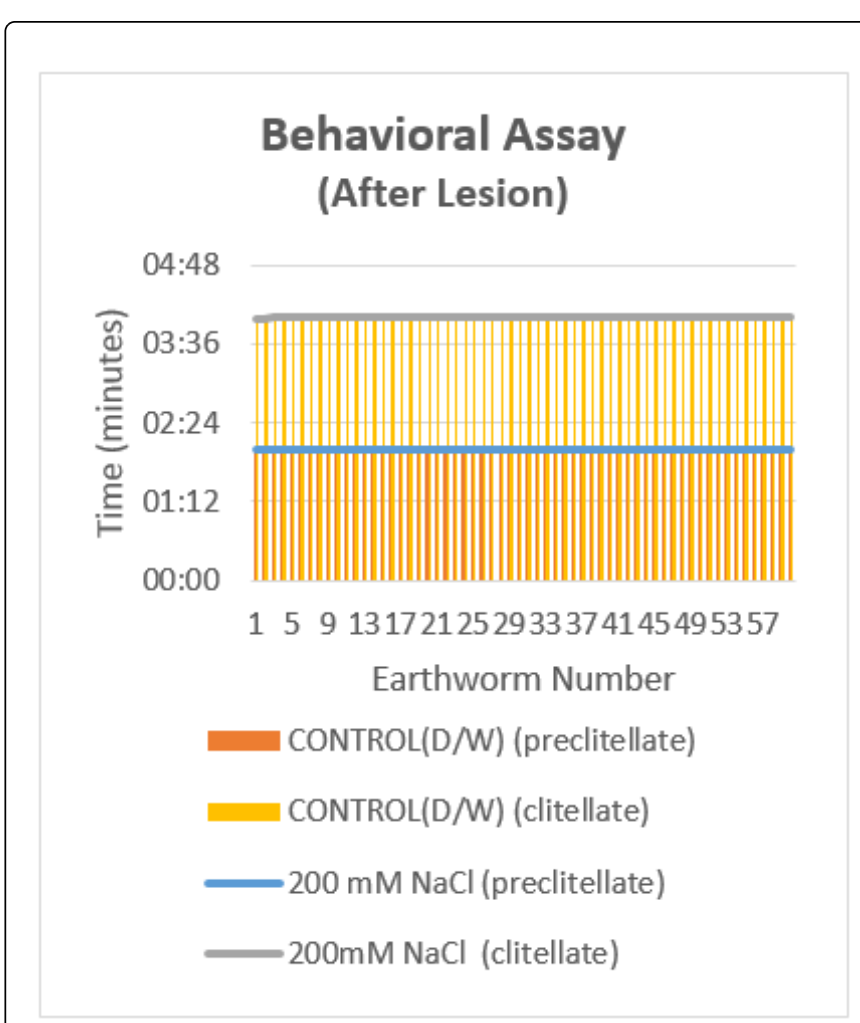

Figure 7: Behavioral assay after lesion.

\section{Discussion}

This work signifies the role of the ventral nerve cord in the locomotory behavior of the model organism. Eisenia fetida, is used for various ecotoxicological studies and more recently has been commonly used to study regenerative mechanisms. This neuronal control on movement has been stated by Gardener and Drewes [12]. To confirm the significance of the ventral nerve cord in the control of locomotion, an assay using a gustatory repellant was set up. Sodium chloride has been tested with various organisms such as Drosophila and $C$. elegans to record a chemosensory response [23-25]. Salinity tests to check adaptability as well as survival rates to Sodium Chloride have been performed in Eisenia fetida $[8,16,26,27]$. Tactile impulses to $\mathrm{NaCl}$ on nerve cord of earthworm have been recorded and an observation that a concentration from $200 \mathrm{mM}$ to $1000 \mathrm{mM}$ shows greater electrical simulation to touch responses has been made $[4,12,20]$.

In order to set up a chemical assay, for confirmatory tests, standard protocols used for C. elegans and Drosophila during chemosensory behavioral tests were modified for our organism [23,25,28].

Distilled water was used as a control as Roots has reported the behavior of $L$. terrestris submerged in water placed in glass tubes and has observed no significant movement or escape behavior [29,30].

As $200 \mathrm{mM}$ was lowest concentration at which significant electrical simulation was recorded, it was taken as test concentration [20]. Preclitellate earthworms showed a faster escape behavior than mature clitellate animals. Reason for this phenomenon was compared to other organisms like $C$. elegans, which have shown an age related decline in locomotory responses [31,32].
On damage on the ventral nerve cord both juvenile as well as mature worms showed loss in activity [33-35]. In order to confirm that this loss in movement was solely due to lesion on ventral nerve cord, a set of 10 animals of both pre-clitellate and clitellate type were subjected to a sham muscular lesion on the dorsal side of the body wall [36-40]. These animals showed no change in locomotory behavior as compared to their previous activity as observed before sham cut $[41,42]$.

Thus it was evident to show the importance of the ventral nerve cord in the escape response shown by earthworm Eisenia fetida.

\section{Acknowledgements}

This research was initially performed under CUBE, HBCSE, TIFR, Mumbai, India. The protocol has been developed under the guidance of Dr. MC Arunan, consultant at HBCSE, Tata Institute of Fundamental Research, India. We would like to thank Dr. Arunan as well as the faculty at CUBE, TIFR for the guidance and helping us with the conceptualization of this chemosensory assay.

\section{References}

1. Dunne K, Verrell P, Usa P (2011) Acute effects of exposure to sodium fluoride on the red compost earthworm Eisenia fetida: Lethality and avoidance behavior. Research Report Fluoride 44: 210-214.

2. Faumont S, Miller AC, Lockery SR (2005) Chemosensory behavior of semi-restrained Caenorhabditis elegans. Dev Neurobiol 65: 171-178.

3. Stein BE, Stanford TR, Rowland BA (2014) Development of multisensory integration from the perspective of the individual neuron. Nature reviews Neuroscience 15: 520-535.

4. Owojori O, Reinecke AJ, Rozanov AB (2008) Effects of salinity on partitioning, uptake and toxicity of zinc in the earthworm Eisenia fetida. Soil Biol Biochem 40: 2385-2393.

5. Parle JN (1963) Micro-Organisms in the Intestines of Earthworms. J Gen Microbiol 31: 1-11.

6. Bely AE (2006) Distribution of segment regeneration ability in the Annelida. Integrative and Comparative Biology 46: 508-518.

7. Mill PJ (1982) Recent developments in earthworm neurobiology. Comparative Biochemistry and Physiology Part A: Physiology 73: 641-661.

8. Whiston RA, Seal KJ (1988) The occurrence of cellulases in the earthworm Eisenia foetida. Biological Wastes 25: 239-242.

9. Laverack MS (1961) Tactile and chemical perception in earthworms-II responses to acid pH solutions. Comp Biochem Physiol 2: 22-34.

10. Yolton LW (1923) The Effects of Cutting the Giant Fibers in the Earthworm, Eisenia Foetida (Sav.). Proc Natl Acad Sci USA 9: 383-385.

11. Fründ HC, Butt K, Capowiez Y, Eisenhauer N, Emmerling C, et al. (2009) Using earthworms as model organisms in the laboratory: recommendations for experimental implementations. Pedobiologia 53: 119-125.

12. Hukema RK, Rademakers S, Jansen G (2008) Gustatory plasticity in C. elegans involves integration of negative cues and $\mathrm{NaCl}$ taste mediated by serotonin, dopamine, and glutamate. Learn Mem 15: 829-836.

13. Heimbeck G, Bugnon V, Gendre N, Häberlin C, Stocker RF (1999) Smell and Taste Perception in Drosophila melanogaster Larva: Toxin Expression Studies in Chemosensory Neurons. J Neurosci 19: 6599-6609.

14. Zhang T, Li S, Sun X, Zhang Y, Gong X, et al. (2015) The Earthworm Eisenia fetida Can Help Desalinate a Coastal Saline Soil in Tianjin, North China. Plos One 10: e0144709.

15. Stein GM, Murphy CT (2012) The intersection of aging, longevity pathways, and learning and memory in C. elegans. Front Genet 3: 259.

16. Drewes CD (1984) Escape Reflexes in Earthworms and Other Annelids. Eaton C (ed.), Neural Mechanisms of Startle Behavior, Springer Science + Business Media, New York. 
Citation: Halwasia S, Dhanesha M, Udhani H, Deore K (2018) Rapid Escape Response - A Behavioral Response on Eisenia fetida. J Vet Sci Technol 9: 502. doi:10.4172/2157-7579.1000502

Page 6 of 6

17. Guzyte G, Sujetoviene G, Zaltauskaite J (2011) Effects of salinity on earthworm (Eisenia fetida). Environmental Engineering, The 8th International Conference, Vilnius, Lithuania, May 19-20.

18. Prosser CL (1934) Impulses in the segmental nerves of the earthworm. Laboratory of Physiology, Harvard University, Cambridge, p: 95-104.

19. Roots BI (1995) The water relations of earthworms ii. Resistance to desiccation and immersion, and behaviour when submerged and when allowed a choice of environment. Department of Zoology, University College, London.

20. Vinson KD, Deason HT (1997) The Procter \& Gamble Company, assignee. Tissue paper containing chemically softened coarse cellulose fibers. U.S. Patent No. 5,679,218. Washington, DC: U.S. Patent and Trademark Office.

21. Aira M, Monroy F, Domínguez J (2006) Eisenia fetida (Oligochaeta, Lumbricidae) Activates Fungal Growth, Triggering Cellulose Decomposition during Vermicomposting. Microb Ecol 52: 738-747.

22. Flack FM, Hartenstein R (1984) Growth of the earthworm Eisenia foetida on microorganisms and cellulose. Soil Biol Biochem 16: 491-495.

23. Eisen GA (1879) On the Oligochaeta collected during the Swedish expeditions to the Arctic regions in the years 1870, 1875 and 1876 (Vol. 15, No. 7). PA Norstedt \& soner.

24. Gates GE (1949) Regeneration in an earthworm, Eisenia foetida (Savigny) 1826. I. Anterior regeneration. The Biological Bulletin 96: 129-139.

25. Adrian ED, Cattell M, Hoagland H (1931) Sensory discharges in single cutaneous nerve fibres. J Physiol 72: 377-391.

26. Kurth JA, Kier WM (2015) Differences in scaling and morphology between lumbricid earthworm ecotypes. J Exp Biol 218: 2970-2978.

27. Kerr M, Stewart AJ (2003) Tolerance test of Eisenia fetida for sodium chloride. J Undergraduate Res 3: 21-25.

28. Sims RW (1985) Earthworms: keys and notes for the identification and study of the species. The Linnean Society of London, United Kingdom.

29. Xiao N, Ge F, Edwards CA (2011) The regeneration capacity of an earthworm, Eisenia fetida, in relation to the site of amputation along the body. Acta Ecologica Sinica 31: 197-204.
30. Dethier VG (1990) Chemosensory Physiology in an Age of Transition. Annu Rev Neurosci 13: 1-13.

31. Friedlander B (1894) Central nervous coordination of earthworm movement. Pflugers Arch Ges Physiol 58: 168-207.

32. Nagano T (1934) Duration of life of earthworms in water and pure gases. Set Rep Tohoku Univ 9: 97-109

33. Cooper EL, Balamurugan M, Huang CY, Tsao CR, Heredia J, et al. (2012) Earthworms Dilong: Ancient, Inexpensive, Noncontroversial Models May Help Clarify Approaches to Integrated Medicine Emphasizing Neuroimmune Systems. 2012: 164152.

34. Liu J, Zhang B, Lei H, Feng Z, Liu J, et al. (2013) Functional Aging in the Nervous System Contributes to Age-Dependent Motor Activity Decline in C. elegans. Cell Metab 18: 392-402.

35. Arendt D, Tosches MA, Marlow H (2016) From nerve net to nerve ring, nerve cord and brain - evolution of the nervous system. Nature Reviews Neuroscience 17: 61-72.

36. Hess WN (1925) Nervous system of the earthworm, Lumbricus terrestris L. J Morphol 40: 235-259.

37. Nielsen C (1999) Origin of the chordate central nervous system-and the origin of chordates. Dev Genes Evol 209: 198-205.

38. Gerber B, Biernacki R, Thum J (2013) Odor-taste learning assays in Drosophila larvae. Cold Spring Harbor Protocols, 2013: pdb-prot071639.

39. Kaplan DL, Hartenstein R, Neuhauser EF, Malecki MR (1980) Physicochemical requirements in the environment of the earthworm Eisenia foetida. Soil Biol Biochem 12: 347-352.

40. Gardner CR (1976) The neuronal control of locomotion in the earthworm. Biol Rev Camb Philos Soc 51: 25-52.

41. Coonfield BR (1932) The peripheral nervous system of earthworms. J Comp Neurol 55: 7-17.

42. Gupta R, Garg VK (2009) Vermiremediation and nutrient recovery of non-recyclable paper waste employing Eisenia fetida. J Hazard Mater 162: 430-439. 